\title{
Alışveriş Merkezlerinin (AVM) Mekânsal Kullanımlarının ve Kullanıcı Eğilim ve Beklentilerin İrdelenmesi; Isparta Kenti Örneği
}

\author{
Fatih UZUN ${ }^{1 *}$, İ. Emre GÜL ${ }^{2}$, Atila GÜL ${ }^{3}$, İsmail UZUN ${ }^{1}$, Ömer Faruk UZUN ${ }^{4}$ \\ ${ }^{1}$ Süleyman Demirel Üniversitesi Mimarlık Fakültesi Mimarlık Bölümü, Isparta, Türkiye. \\ ${ }^{2}$ Süleyman Demirel Üniversitesi Mühendislik Fakültesi Inşaat Mühendisliği Bölümü, Isparta, Türkiye. \\ ${ }^{3}$ Süleyman Demirel Üniversitesi Mimarlık Fakültesi Peyzaj Mimarlığı Bölümü, Isparta, Türkiye. \\ ${ }^{4}$ Süleyman Demirel Üniversitesi FBE Peyzaj Mimarlığı ABD Doktora Programı, Isparta, Türkiye. \\ *e-mail: fatihuzun575@gmail.com
}

Öz

Türkiye'de 1990'lı yıllardan itibaren sayıları hızla artan alışveriş merkezleri (AVM) kentsel yaşamın önemli bir parçası ve bağımlısı haline gelmişlerdir. Ancak AVM'lerin yakın bir gelecekte bir kısmı için cazibenin azalması ve beraberinde atıl hale gelmesi de söz konusudur. Türkiye'deki ekonomik ve sosyal ortam tam olarak değerlendirilmeden, dünyadaki popüler alışveriş merkezleri örneklerine benzer tasarımlar yapılması nedeniyle, Türkiye'deki kullanıcı beklentilerine cevap verememesi sonucunu ortaya çıkarabilecektir. Bu çalışmanın amacı Isparta kentinde mevcut olan ve faaliyet gösteren IYASSPARK ve CENTRUM Garden AVM'lerin kullanıcı eğilim ve beklentilerinin belirlenmesi ve irdelenmesidir. Çalışmada yüz yüze anket çalışması yapılarak anket sonuçları SPSS programı kullanılarak yüzde değerleri ve ki kare önemlilik düzeyleri belirlenmiş ve yorumlanmıştır. Çalışmanın sonucunda, Isparta'daki mevcut AVM'lerin mekânsal işlevsellikleri açısından yeterli olmadığı ve eksikliklerin bulunduğu ortaya çıkmıştır. Bu eksiklik ve yetersizliklerin başında; AVM'lerin kapalı, suni ve tekdüze mekân konseptinde olması ve dış mekân ile kombine edilmemesi, mevcut otopark kapasitesi, kültürel etkinlik alanları, yetişkinlere yönelik etkinlik mekânları, mağaza ve dükkân sayısı ve çeşitliliği gibi sıralanmıştır. Sonuçta, AVM'lerin sadece alışveriş yapma ve gezme mekânları olarak değil, aynı zamanda kent kültürü ve kentsel mekânlar uyumlu olacak şekilde her kesimin rekreasyonel ihtiyaçlarının karşılanacağı bir mekân olarak kurgulanması gerektiği önerilmektedir.

Anahtar Kelimeler: Alışveriş Merkezleri, Isparta, mekân tasarımı, IYASPARK AVM, CENTRUM Garden AVM

\section{Investigation of Spatial Uses of Shopping Centers and User Trends and Demands; Isparta City Example}

\begin{abstract}
Shopping Centers (SC), which have been increasing rapidly since 1990 in Turkey, have become an important part and addict of urban life. However, it may be possible for the shopping malls to become less attractive and idle for some of these centers in the near future. Without fully evaluating the economic and social environment in Turkey, similar designs to popular shopping malls in the world will not be able to respond to user expectations in Turkey. The purpose of this study is to determine and examine trends and expectations in spatial usage of IYAS and CENTRUM Garden Shopping Centers that are present and active in Isparta. In the study, a questionnaire survey was conducted and the results of the questionnaires were determined and interpreted using the SPSS program.
\end{abstract}

As a result of the study, it became clear that existing shopping malls in Isparta were not sufficient in terms of spatial functionalities and there were deficiencies. At the beginning of these deficiencies; Shopping malls are in

Geliş Tarihi: 12/09/2017 - Kabul Tarihi: 12/09/2017

*Bu çalışma; 10-12 Şubat 2016 tarihinde Erzurum'da gerçekleştirilen “Uluslararası Kış Şehirleri Sempozyumunda (International Winter Cities Symposium)" sözlü Poster olarak sunulmuş olup özet veya tam metin bildiri olarak basılmamıştır. Bu çalışma ilk kez tam metin olarak yayınlanmıştır. 
the concept of closed, artificial and uniform spaces and are not combined with outdoor spaces, inadequate parking lots, insufficient cultural activity areas, inadequate space for adults, lack of shops and shops and diversity. As a result, it is suggested that shopping malls should be constructed not only as shopping and traveling places but also as a place to meet the recreational needs of every segment in order to be compatible with urban culture and urban space.

Key words: Shopping Centers, spatial design, Isparta, IYASPARK, CENTRUM Garden

\section{Giriş}

İçinde bulunduğumuz 21. yüzyılda mekânsal ve demografik büyüme gösteren kentsel alanlarda yaşanan çok yönlü ve hızlı değişimler/gelişimler yaşam koşullarını sınırlandırmış ve zorlaştırmıştır. Bu bağlamda; kentsel alanlardaki sosyal, kültürel ve ekonomik boyutta yaşanan çok yönlü etkileşim ve gelişmeler ile mekânlar arası ulaşılabilirlik ve hareketliliğin artması, yeni talepleri ve ihtiyaçları da beraberinde getirmiş, farklı ve yeni sosyal mekânların ortaya çıkmasına neden olmuştur.

AVM olgusunun ilk habercileri, 1900 'lerde $A B D$ ve Avrupa'da görülmeye başlanan ve geleneksel alışveriş olgusunu değiştiren süpermarketlerdir (department store) (Zukin, 1998). Ancak günümüzde bildiğimiz AVM'lerin ortaya çıkışı 1950'leri bulmuştur (Zukin,1998). AVM'lerin gelişimini, önce banliyölerdeki konut alanlarının ihtiyaçlarına yönelik olarak, sonrasında ise kentlerdeki tüketim toplumunun ve tüketim mekânlarının gelişimine ve dönüşümüne paralel olarak değişim gösterdiğini aktarmaktadır. 20. yüzyılın ortalarında banliyölerdeki konut alanlarının çekiciliğini arttıran bir unsur olarak kullanılan AVM'ler, giderek başlı başına kazanç getiren yatırımlar haline gelmiştir. Böylece kent içinde de alışveriş merkezleri kurulmaya başlanmıştır (Zukin, 1998). Çağdaş alışveriş merkezinin öncüleri, 19. yüzyıl sonlarında ortaya çıkan pasajlar ve büyük mağazalardır (White ve Sutton, 2001). Pasajlar, alışveriş yapılarının kentten yalıtılmasının ilk sinyallerini vermiş ve bu yapılarda vitrin bakma ve alışveriş yapma bir boş zaman etkinliğine dönüşmüştür (Backes, 1997). Pasajlar ve büyük mağazalar ile başlayan "kentsel mekân-alışveriş mekânı bütünlüğündeki kopma (Birol, 2003), günümüzün kapalı kutu içerisindeki alışveriş merkezlerinde doruk noktasına ulaştırmıştır.

Ilk alışveriş merkezinin tasarımcısı olan Victor Gruen (1960)'de bu sorundan yola çıkarak, kentlerde insanların, trafik, sıkıcı çalışma ortamları, soyutlanmış konut alanları gibi ortamlardan uzaklaşarak kentlerde sağlıklı bir toplumsal yaşam kurulabilmesi için yeni bir sosyal mekân anlayışının oluşturulması gerektiğini savunmuştur. Bu sosyal mekânlar, trafik sorunundan ve gündelik hayatın sıkıcılığından bunalan insanlar için bir kaçış noktası ve ticari bir toplanma merkezi olabileceğini ve dolayısıyla, 20. yüzyılın başlarında, kentlerde yaşamın ve mekânsal kurgunun farklı aktivite alanlarına bölünmesiyle, anlamı boşalan kent merkezi fikrini alışveriş merkezlerinde yaratılacak olan kent mekânı doldurabileceği ve hatta bu mekânların, geçmişte antik Yunan Agorası, Ortaçağ pazar alanı ya da kent meydanlarının tarihte yaptıkları görevi günümüzde de üstlenebileceği düşünülmüştür (Gruen, 1960).

Bu düşüncelerine ek olarak, alışveriş merkezlerinin yalnızca ticari aktiviteye ev sahipliği yapmanın ötesinde kullanıcılara kapalı ve korunaklı bir yaya ortamı sunarak, ticari aktivitenin yanı sıra sosyal ve kültürel faaliyetleri de barındırmaları gerektiğini savunmuştur (Vural Aslan, 2009). Amerikan kentleri gibi geniş bir alana yayılan, trafik ve ulaşımın büyük bir sorun haline geldiği kentlerde bu gereklilik daha büyük oranda hissedilmiştir (Kowinski, 1985). Gruen'in bu düşüncelerle ilk tasarlamış olan alışveriş merkezi Northland Alışveriş Merkezidir. Bu merkez, tek katlı olarak inşa edilmiş çeşitli bina kitlelerinin birbirlerine açık alanlar ile bağlanmasından oluşmuş bir komplekstir (Gruen, 1973). Gruen'in tasarladığı ikinci alışveriş merkezi ise Southdale'dir (Şekil 1.1 ve 1.2). Bu merkezi tasarlarken hedefi ise hem satıcılar, hem de tüketiciler için karlı olan ve toplumsal paylaşım hissi geliştiren birçok mağazanın bir arada olduğu tamamen kapalı bir merkez inşa edilmesidir (Kowinski, 1985). Gruen'in tasarladığı ilk alışveriş merkezleri olan Amerika'daki Northland ve Southdale'den sonra, Avrupa ve dünyanın birçok yerinde çok sayıda alışveriş merkezi tasarlanmıştır. Bu merkezlerin taşıdıkları ekonomik misyon yanında, yeni bir kentsel yaşam önerisi getirmeleri ile ilgili olan sosyal misyon, hem ekonomistlerin, hem sosyal bilimcilerin, hem de tasarımcıların oldukça ilgisini çekmiştir. (Vural Aslan, 2009). 

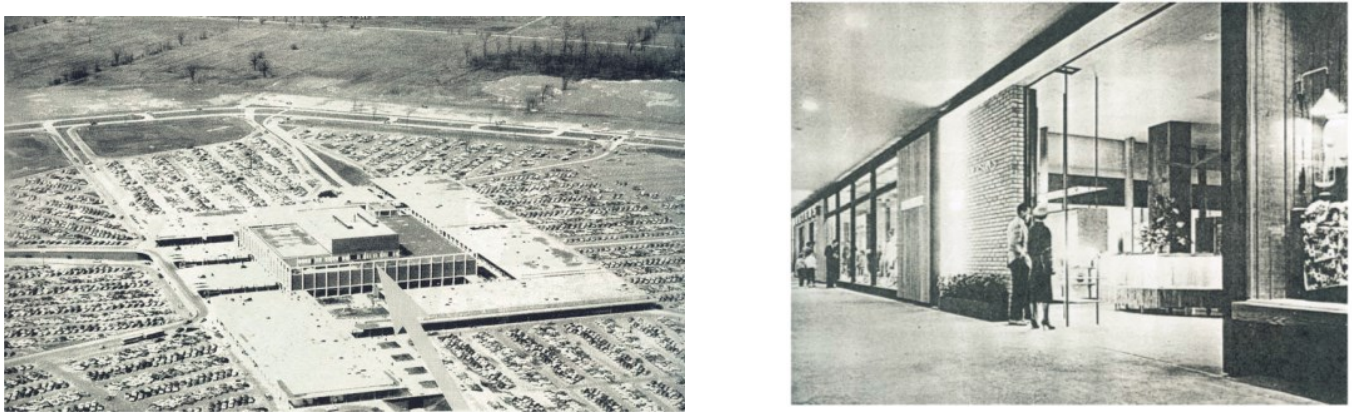

Şekil 1.1 ve 1.2. Southdale AVM

1970 ve 1980 'lerde AVM'ler, tüketim eğilimin yükselmesine koşut olarak, müşterilerin alışverişte daha fazla zaman geçirmesi için yeni stratejiler oluşturulmuştur. 1980'den sonra belli bir dereceye kadar, banliyö AVM'lerinden kentsel, ofis, alışveriş ve eğlenceyi de içeren karma kullanımlı komplekslere doğru coğrafi ve kültürel bir değişim yaşanmıştır (Zukin 1998). Böylece küresel kentin tüketimci doğasının, kültür ve sanatı da içeren yeni bir tür alışveriş temeli kazanmıştır. 1980'lerin ortalarından itibaren (özellikle 1990 yıllarının başı) Türkiye uygulanan liberal ekonomi politikalarının yansımaları olarak dışa bağımlı gelişme stratejisi ile yeni bir ekonomik yapılanma süreci söz konusu olmuştur. Bu yapılanma ile çok ortaklı ve çok uluslu yeni yapılanmalar ve yabancı sermayeli yatırımlar ortaya çıkmıştır.

Bu yeni ekonomik yapılanma ve yatırımlar, Türkiye'de kişi başına düşen milli gelirin artması, kredi kartı kullanımının artması, kişi başına düşen araç sahibi olma oranının artması, kadınların ekonomik hayatın içinde aktif rol almaları, kentsel yaşam kültürünün ve taleplerinin değişmesi gibi makro ve mikro ölçekte ekonomik değişimleri de beraberinde getirmiş ve Türkiye'yi tüketen bir toplum konumuna taşımıştır.

Tüketim ve markalaşma eğilimi, tüketim mekânlarının da değişmesine ve yeni yaklaşımları da beraberinde getirmiştir (Odabaşı, 1999; Tokatlı ve Boyacı, 1999; Vural, 2003; Erkip, 2005).

1988 yılında Türkiye'deki ilk alışveriş merkezi olan Galleria, devlet tarafından yap-işlet devret modeli ile kurulmuştur. 1990 yıllarından itibaren tüketim odaklı bir yaşantının ilk uygulaması olarak ifade edilmektedir. Galleria'nın açılışını daha sonraki yıllarda İstanbul'da açılan Nova Baran (1990), Atrium (1992), Capitol (1993), Carrefour (1993) ve Ankara'da açılan Atakule (1988) ile Karum (1993) izlemiştir. Galleria'nın açılışından sonra bir anda çoğalan alışveriş merkezlerine bir yenisi olan Akmerkez (1993) eklenmiştir (Vural Aslan, 2009). 2009 yılında sayısı 208'e ulaşmış olan AVM'lerin çoğunluğu İstanbul'da olmak üzere günümüzde yaklaşık 400'den sayıda bulunduğu görülmektedir.

Alışveriş merkezleri, kent kültürü ile tüketicinin buluştuğu bir mekândır. Tüketim toplumunun yeni kentsel mekânı olan alışveriş merkezleri sermayeyi paraya dönüştüren, tüketicilerin ihtiyaçlarına cevap veren mekân olarak kentte yaşanılanları yeni ve farklı bir yorumla sunmaktadır. Kentte kurulan bireyler arası ilişkilerin farklı bir şekilde önceden düzenlenmiş olarak kurulduğu, kenttekinden farklı olarak olumsuz koşullardan uzaklaştırılmış, güvenli bir ortam sunan alışveriş merkezleri kent merkezini çeşitli yönleriyle taklit ederek, yeni bir kentsel mekân oluşturmuştur. Alışveriş merkezleri adeta küçük bir kenti andıran sosyal yaşam mekânı olarak kent mekânını kendi içerisinde yeniden kurgulamış bir görünüm sunmaktadır (Ceylan, 2010).

Alışveriş merkezlerinin yatırım, uygulama ve yönetim maliyetlerinin yüksek olması nedeniyle çok yönlü ve uzun süreli ciddi bir organizasyonla gerçekleştirilmesi gerekmektedir. Ayrıca AVM'ler arasında ciddi bir rekabeti de beraberinde getirmektedir. Özellikle AVM'lerin mekânsal büyüklüğü, mimarisi ve çeşitliliğin ortaya koyduğu cazibe merkezi özelliği ile çok yönlü kullanımını artırmaktadır. Bununla birlikte diğer küçük ölçekli esnafın da olumsuz yönde etkilenmesine de yol açtığı 
düşünülmektedir. Alışveriş merkezleri artık günümüzde alışverişin ötesinde bir olgu haline gelmiştir. Teknolojinin internet üzerinden alışverişe sınırsız olanak sağlaması, insanların ekran başından ya da telefonları ile alışveriş yapmalarının kolaylaşması, AVM'leri giderek daha çok sosyal ve eğlence intiyaçlarının karşılanıp bu şekilde vakit geçirilebilen rekreasyonel açık ve kapalı mekânların bir arada bulunduğu konsept haline dönüşmesi noktasına getirmektedir. Örneğin İzmir'de 2015 yılında açılan Mavi Bahçe AVM örnek olarak verilebilir (Şekil 1.3).

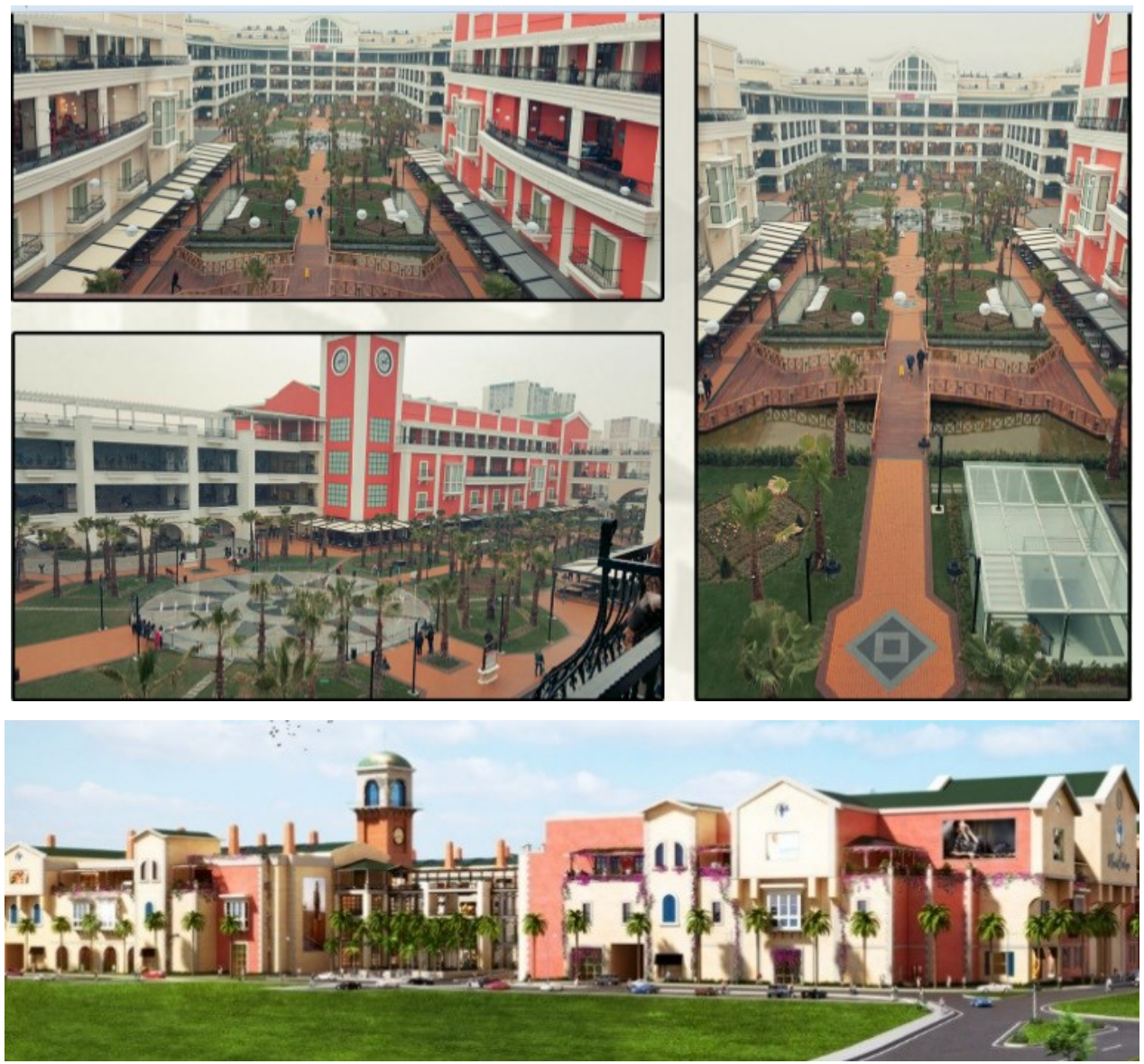

Şekil 1.3. İzmir Mavi Bahçe AVM konsepti

Isparta kentinin, ülkesel ölçekteki yaşanan ekonomik gelişmelerden de etkilenmesi söz konusu olmasına rağmen bu gelişme çok yavaş gerçekleşmiştir. Isparta kenti, özellikle Süleyman Demirel Üniversitesinin (SDÜ) 1992 yıında kurulması ile birlikte söz konusu değişim ve gelişimini daha net olarak kendinde göstermiştir. Üniversitenin yalnızca eğitim öğretim alanında değil, aynı zamanda bünyesinde görev yapan idari ve akademik personelin istihdamı, mevcut öğrenci potansiyeli ve bu kitleye hizmet sunan çok çeşitli işletmeler ile sosyo-ekonomik-kültürel alanda çok yönlü fayda sağlaması söz konusudur (Gültekin vd., 2008). Bunun en önemli göstergesi ise 1998 yılından bu güne özellikle büyük marketlerin faaliyete geçmesi ve sayısının artmasıdır.

Isparta kentinde, AVM konseptinde mekânlar, 2010 yılında IYASPARK AVM ve 2015 yılında ise CENTRUM Garden AVM'nin açılışı ile ortaya çıkmıştır.

Bu çalışmanın amacı; kentsel mekânlarda hızla yayılan AVM'lerin kullanıcılarının, mevsimsel olarak tercihleri, kullanıcı eğilim ve beklentilerinin ortaya çıkartılması ve AVM'lerin mekânsal işlevsellikleri açısından Isparta kenti örneğinde irdelenip, öneriler sunulmasıdır.

Bu bağlamda; alışveriş merkezleri ile ilgili yapılacak çalışmalarda, farklı disiplinlerdeki araştırmacılara yeni bir ufuk açması ve Türkiye'deki kentsel ve toplumsal strüktürde alışveriş merkezlerinin önemine ve mekânsal özelliklerinin değerlendirilmesine yönelik eleştirel bir yaklaşımın ortaya konulması söz konusu olabilecektir. Ayrıca, bu çalışmalar, tüketim toplumu ve özelliklerinin mekânsal yansımaları ile ilgilenen sosyal bilimciler ve ekonomistlere ise yeni tartışma zeminleri de oluşturabilecektir. 


\section{Materyal ve Yöntem}

Bu çalışmada materyal olarak Isparta kentinde AVM konseptinde faaliyet gösteren IYASPARK AVM ve CENTRUM Garden AVM'dir. IYASPARK AVM iki katlı olup çok sayıda mağazalar ve dükkânlar, yiyecek ve içecek yerleri, restoran, kafe, WC, kapalı ve açık alanda otoparklar, çocuk oyun alanları, sinema salonu, terzi, kuaför, vb. gibi işlevsel mekânlar bulunmaktadır. Yakın çevresinde Isparta Otogar, IYAŞ market, Süleyman Demirel Kongre ve Sergi Merkezi, restoran, kafeterya, dükkânlar gibi birimler bulunmaktadır. IYAŞPARK AVM 2010 yılında tesis edilmiş, iki katlı ve dikdörtgen forma sahiptir. Kent merkezine çok yakın olup (yaklaşık $2 \mathrm{~km}$ ) Isparta Valilik Binasından yaklaşık olarak $2 \mathrm{~km}$ mesafe uzaklıktadır (Şekil 2.1 ve 2.3.).

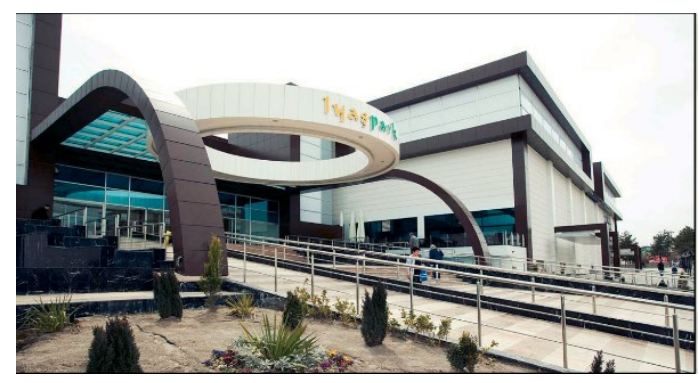

Şekil 2.1. IYAŞPARK AVM

CENTRUM Garden AVM içinde çeşitli mağaza ve dükkânlar, Migros market, sinema salonu, kafeterya ve restaurant, açık ve kapalı otopark, WC, gibi işlevsel mekânlar bulunmaktadır. 2015 yılında ise kurulan AVM iki katlı ve dikdörtgen forma sahiptir. Kent merkezine çok yakın olup Valilik binasına yaklaşık $2,5 \mathrm{~km}$ mesafesindedir (Şekil 2.2 ve 2.3 ).

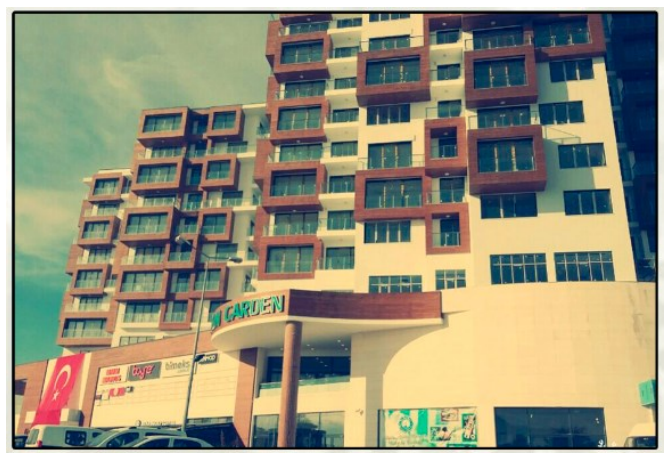

Şekil 2.2. CENTRUM Garden AVM

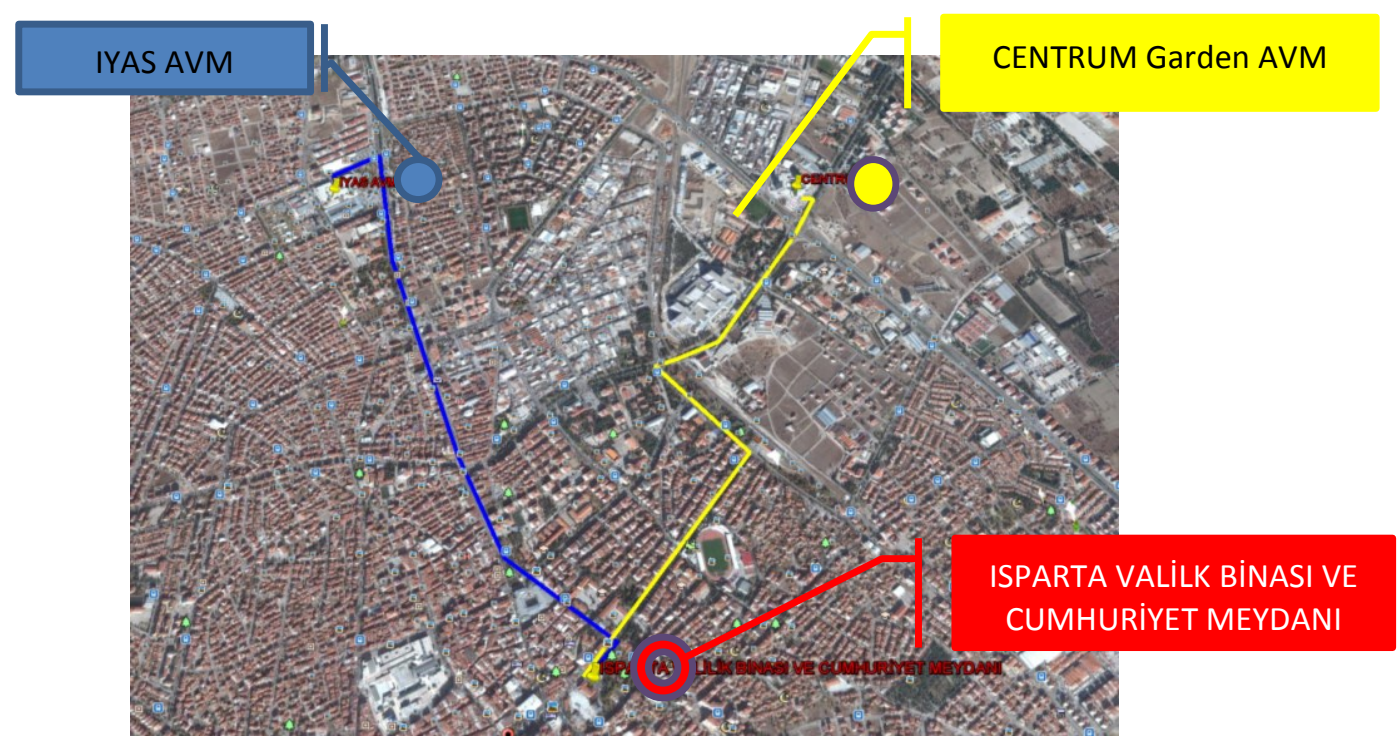

Şekil 2.3. Isparta AVM'lerin kent merkezindeki konumu 
Çalışmanın yönteminde, Isparta'da faaliyet gösteren mevcut IYAŞPARK AVM ve CENTRUM Garden AVM'lerde kullanıcıların mekânsal kullanım eğilimleri ve beklentilerini belirlemek üzere, kullanıcılara yüz yüze toplam 130 adet anket çalışması yapılmışır. Kullanıcıların mekânsal kullanım eğilimleri ve beklentilerine yönelik yüzde değerleri belirlenmiş ve arasında Pearson Chi-Square testleri uygulanarak $p=<0.01$ açısından anlamlı ilişkisi olanlar yorumlanmıştır.

Anket sorularında tek cevaplı ve açık uçlu sorular olup cevaplama süresi yaklaşık 15 ila 20 dakika arasında sürmüştür ve anketteki cevaplanma oranı ise $\% 95$ 'tir.

Örnekleme hesaplanmasında; $n=N x p x q x Z \alpha^{2} /(N-1) x d^{2}$ formülü kullanılmıştır (Yazıcıoğlu ve Erdoğan, 2004). Formülde Isparta kent merkezi nüfusu 241.723 olarak alınmıştır. Formüldeki (N=241723, p:0,5, $\mathrm{q}: 0,5, \mathrm{~d}: 0,1$ ve $\alpha: 0,05 \rightarrow$ Z $\alpha: 1.96)$ değerler kullanılarak $n: 96$ minimum sınır değer çıkmasına rağmen 130 kullanıcıya anket çalışması uygulanmıştır. Veriler SPSS Statistics 20 programında değerlendirilmiştir. Anket sonuçlarına göre Isparta kentindeki mevcut AVM'lerin mekânsal kullanımına yönelik öneriler de ortaya konulmuştur.

\section{Bulgular ve Tartışma}

\subsection{Ankete Katılanların Genel Profili}

Ankete katılanların \%61,2'si kadın \%38,8'i ise erkektir, \%48,1'i $17-25$ ve $\% 47,3^{\prime}$ ü ise $26-50$ yaş grubundadır, \%62,8'i bekâr, \%58,9'u üniversite öğrencisi ve mezunu, \%49,6'sı öğrenci ve \%41,9'u ise kamu çalışanıdır. Gelir durumu açısından \%39,5'u 1000 TL ve altında, \%36,4'ü ise 2000-4000 TL arasında bir gelir düzeyine sahiptir (Çizelge 3.1).

Çizelge 3.1. Ankete katılanların genel profili

\begin{tabular}{lll}
\hline Profil özellikleri & & \% Değeri \\
\hline Cinsiyet & Kadın & 61,2 \\
& Erkek & 38,8 \\
\hline Yaş Grupları & $<17$ yaş grubu & 3,0 \\
& $17-25$ & 47,8 \\
& $26-50$ & 47,8 \\
& $50<$ & 1,5 \\
\hline Eğitim Durumu & Ilköğretim & 3,0 \\
& Lise & 20,1 \\
& Lisans & 58,2 \\
& Lisansüstü & 18,7 \\
\hline Meslek Durumu & Öğrenci & 49,3 \\
& Memur & 43,3 \\
& Özel sektör çalışanı & 6,7 \\
& işsiz &, 7 \\
\hline Medeni Durumu & Evli & 37,3 \\
& Bekâr & 62,7 \\
\hline Gelir Durumu & $<1000$ TL & 40,3 \\
& $1000-2000$ TL & 11,9 \\
& $2001-4000$ TL & 35,8 \\
& $4001-6000$ TL & 8,2 \\
& 6001 TL $<$ & 3,7 \\
\hline
\end{tabular}

\subsection{Ankete Katılanların Isparta AVM'lerinde Mekânsal Kullanımına Yönelik Eğilimler ve Beklentileri}

Ankete katılanların kentsel mekân olarak büyük çoğunluğu AVM $(\% 47,0)$ ve kafeterya $(\% 27,6)$ gibi mekânlarda zaman geçirmektedir (Şekil 3.1). AVM'yi kullananların içinde en çok \%43,3'ü kış mevsimini, \% 35,8'i ise tüm mevsimleri tercih etmektedirler (Şekil 3.2). AVM'leri ziyaret etme sıklıkları açısından en fazla hafta sonları $(\% 44,8)$ ve 2 günde bir $(\% 30,6)$ olmak üzere tercih ettikleri 
görülmektedir (Şekil 3.3). AVM'leri tercih etme nedenleri özellikle çeşitli marka mağaza ve dükkanların bulunması $(\% 25,4)$ olumsuz hava koşulları (özellikle sıcak, soğuk ve yağışı zamanlar) $(\% 23,5)$, aktivite çeşitliliğinin $(\% 17,2)$ fazla olması gibi nedenleri ile tercih edilmektedir (Şekil 3.4). AVM'lerde kalış süresi genelde \% 50'si 2-4 saat arasında vakit geçirdiklerini, \%40,3 ü ise 2 saatten az sürede vakit geçirdiklerini belirtmektedir (Şekil 3.5). Ankete katılanların \%55,2 sinin Isparta'daki AVM'lerde mekânsal ve işlevsel olarak yeterli olmadığını, \%41'i ise yeterli olduğunu düşünmektedir (Şekil 3.6). Isparta'da mevcut AVM'lerin doğal ortamdan uzak suni mekânlar olduğunu ifade edenlerin oranı ise $\% 73,1^{\prime}$ dir (Şekil 3.7). Genel olarak ankete katılanların büyük bir çoğunluk $(\% 73,1)$ AVM'lerde mimari konsept tipi olarak çok katlı kapalı ve açık mekânların bir arada olmasını, \% 18 i ise tek katlı kapalı ve açık mekânların olması gerektiği belirtilmektedir (Şekil 3.8.).

Ankete katılanların AVM'lerde öncelikli olarak çok çeşitli mağaza ve dükkânların bulunmasını $(\% 62,7)$, güvenli olmasını (\%47,8), kültür etkinlik alanlarının (sinema tiyatro, sergi salonları vb.) (\%44,8), peyzaj mekân düzenlemelerinin olmasını (\%43,3), kapalı alanda gezilebilir ve oturulabilir yerlerin olmasını, açık ve kapalı otoparkların olmasını $(\% 42,5)$, kolay verişebilir ulaşımın olmasını $(\% 38,8)$, kaliteli ürünlerin mevcut olmasını $(\% 35,1)$ gibi kriterlerin önemlilik arz ettiğini ifade etmektedir (Şekil 3.9).

Ankete katılanların AVM'lerde gözlemledikleri eksiklikler şu şekilde belirlenmiştir. IYAS AVM de en önemli eksikliklerin başında dış mekân düzenleme alanlarının yetersiz olması $(\% 50,7)$, kültürel etkinlik alanlarının yetersiz olması $(\% 41,8)$, kapalı ve açık otopark alanlarının yetersiz olması $(\% 35,1)$ yetişkin oyun alanlarının yetersiz olması $(\% 34,3)$, dinlenme ve oturma alanlarının yetersiz olması $(\% 32,1)$, manyetik etkinin fazla olması $(\% 23,1)$, estetik mekân algısının zayıf olması $(\% 19,4)$ gibi ifade edilmiştir (Şekil 3.10).

CENTRUM Garden AVM'de ise kapalı ve açık otoparkların yetersiz olması (\%47,8), dış mekân düzenlemelerin yetersiz olması (\%47,8), kültürel etkinlik alanların yetersiz olması $(\% 43,3)$, yetişkin oyun alanların yetersiz olması $(\% 21,6)$, mağaza ve dükkan sayısının az olması $(\% 20,1)$, dinlenme ve oturma alanlarının yetersiz olması $(\% 20,1)$, mekânsal ulaşım ve sirkülasyon erişe bilirliğinin yetersiz olması (\% 20,1) gibi ifade edilmiştir (Şekil 3.11.).

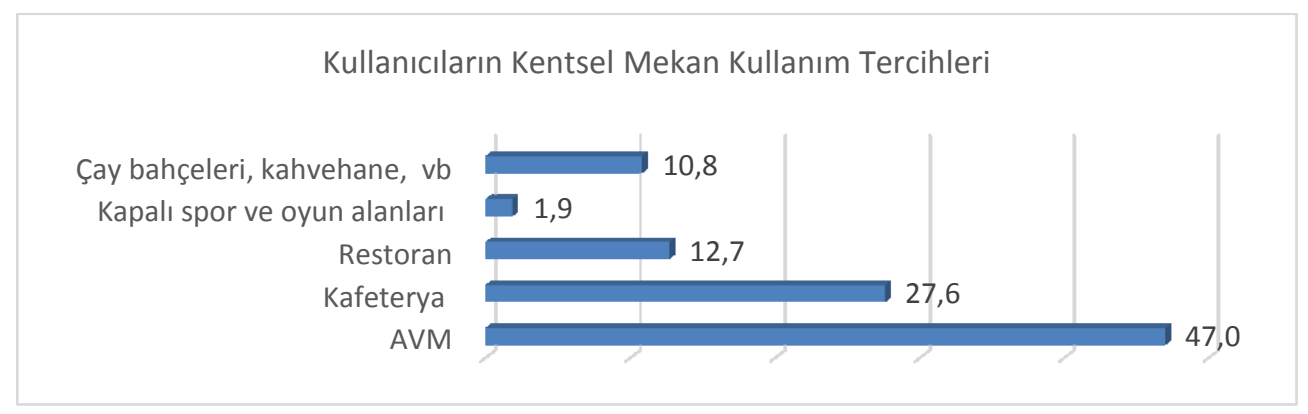

Şekil 3.1. Mekân kullanım tercihleri

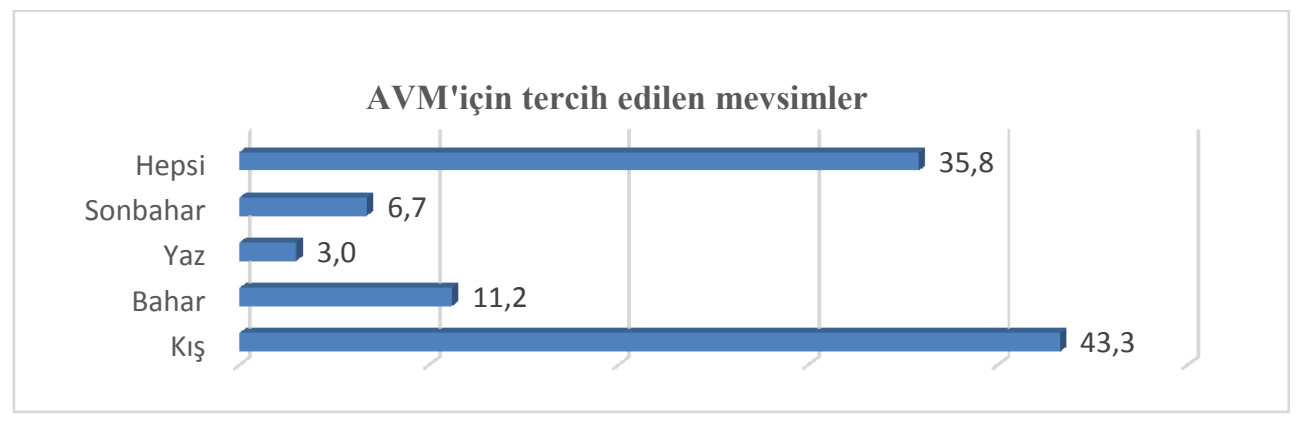

Şekil 3.2. AVM kullanımı için tercih edilen mevsimler 


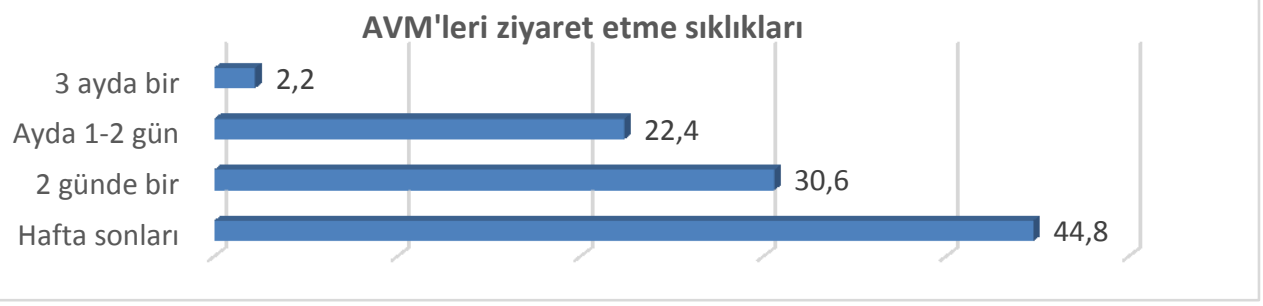

Şekil 3.3. AVM'leri ziyaret etme sıklıkları

AVM'leri tercih nedenleri

Çeşitli marka mağaza ve dükkanların birarada.. Yemek seçeneklerinin fazla olması Şehir merkezine yakın olması Aktivite çeşitliliğin fazla olması Alışveris amaçlı gezmek Olumsuz hava koşullarından dolayı AVM yi gezmek

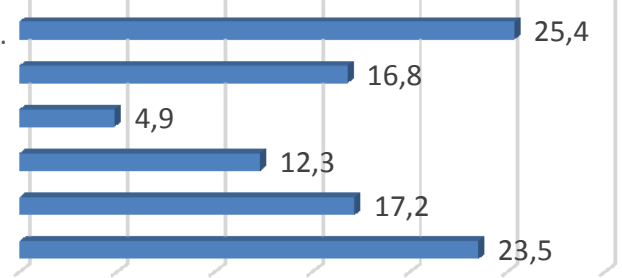

Şekil 3.4. AVM'leri tercih etme nedenleri

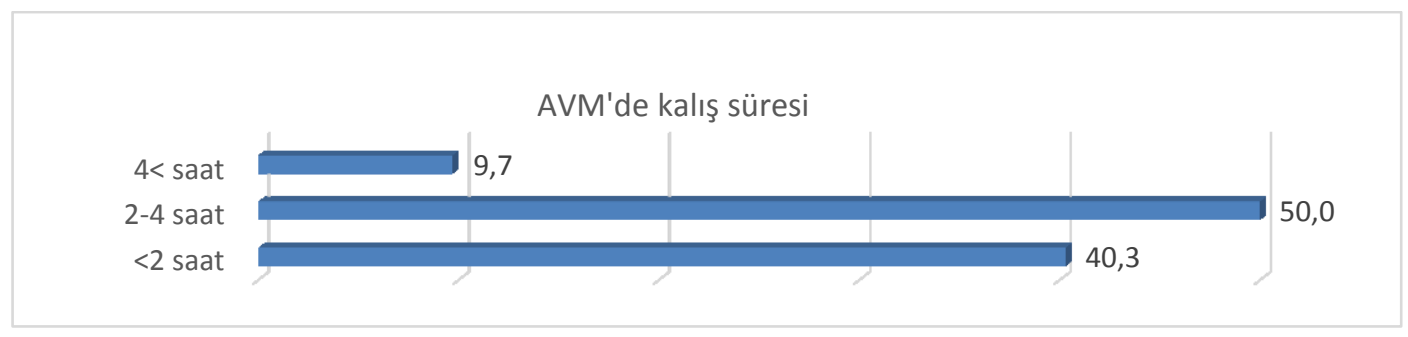

Şekil 3.5. AVM’lerde kalış süresi ortalamaları

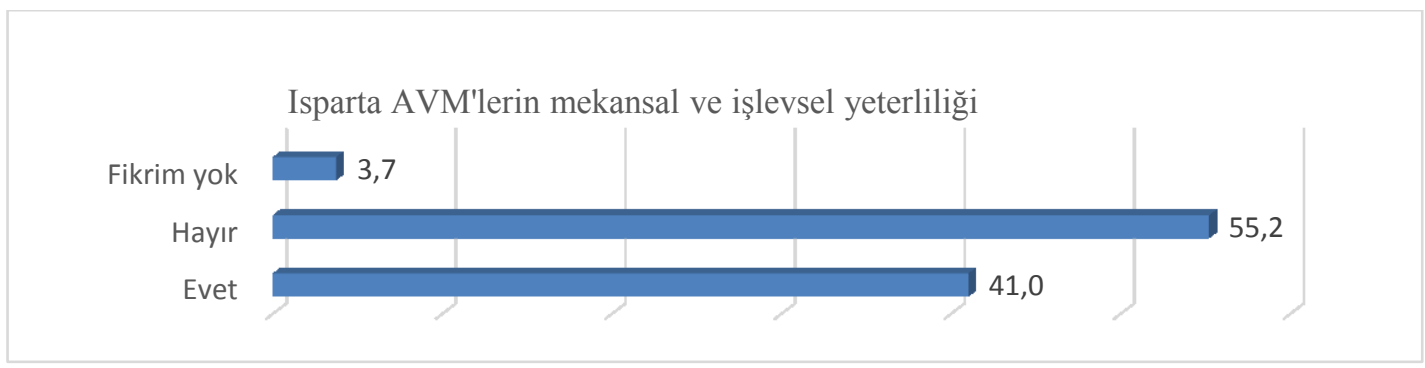

Şekil 3.6. AVM'lerin mekânsal ve işlevsel yeterliliği

AVM'lerin doğal ortamdan uzak suni mekanlar olduğunu düşünüyor musunuz?

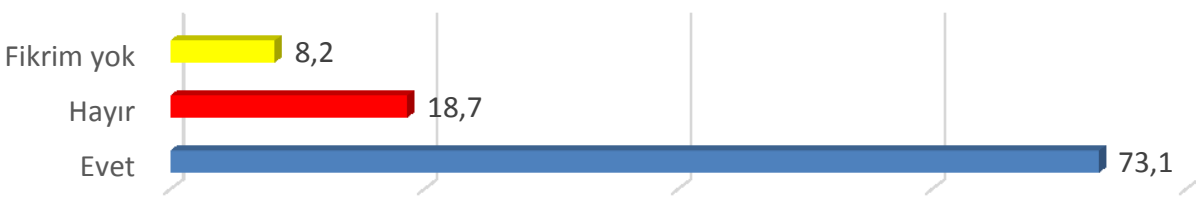

Şekil 3.7. AVM'lerin in suni mekân olduğunu düşünenlerin yüzde değerleri 
AVM'lerde mimari konsept tipi

Tek katlı kapalı mekan olmalı

Tek katı açık ve kapalı olmalı

Çok katlı kapalı olmalı

1,5

Çok katlı açık ve kapalı mekanlar olmalı

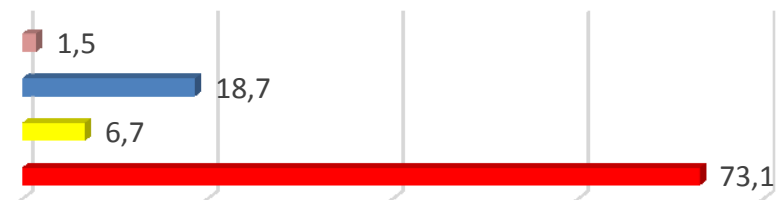

Şekil 3.8. AVM'lerde mimari konsept tipi talebi yüzde değerleri

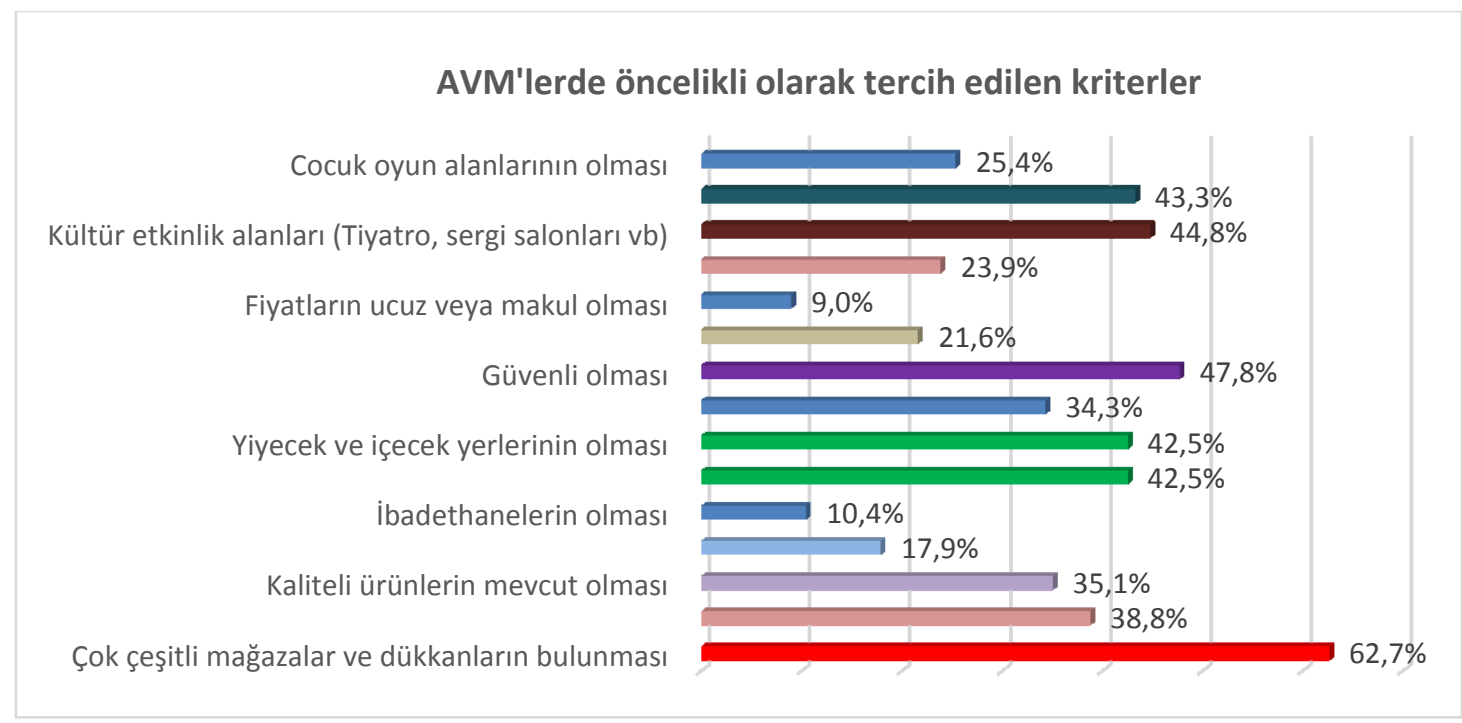

Şekil 3.9. AVM'lerde öncelikli olarak tercih edilen kriterler

IYAS AVM 'ye önerilen eksiklikler

Mekan içi kullanılan renk ve malzemelerin estetik...

Mekansal ulaşım ve sürkülasyon erişebilirliği...

Spor ve oyun alanlarının eksik olması

ibadethane gibi yerlerin yetersiz olması

Doğa ile ilgili hiçbir tasarımın bulunmaması

Dış mekan (peyzaj) düzenlemelerin yetersiz olması

Manyetik alan etkisinin fazla olması

Yetişkin oyun alanlarının olmaması

Geleneksel ürün satış yerlerinin az olması

Ürün çeşitliliğinin az olması

Estetik mekan algısının zayıf olması

Mağaza ve dükkanların yetersizliği

Kültürel etkinlik alanların yetersizliği

Sigara icme alani yetersizliği

Dinlenme ve oturma alanlarının yetersizliği

Kapalı ve açık otopark alanları

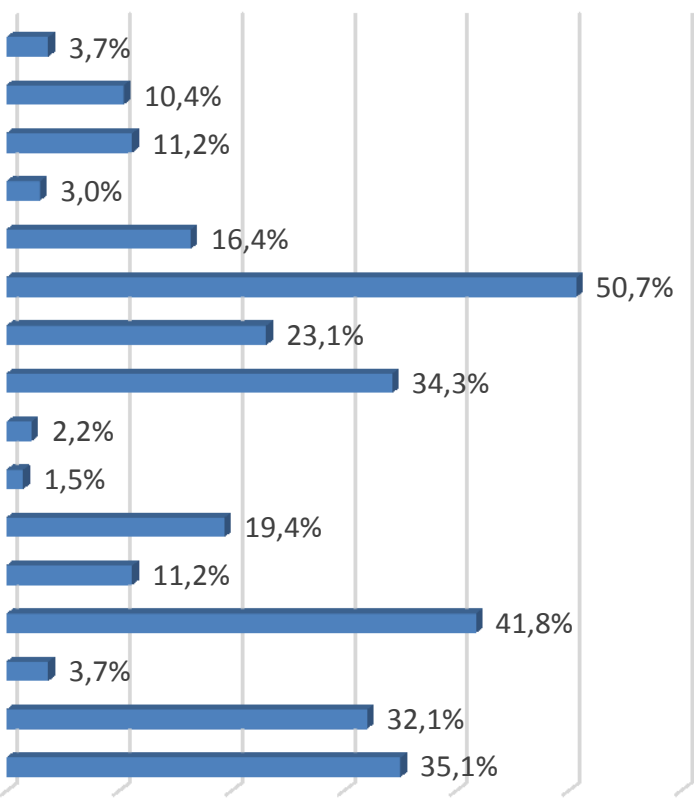

Şekil 3.10. IYAS AVM'de mevcut eksikliklerin yüzde oranları 


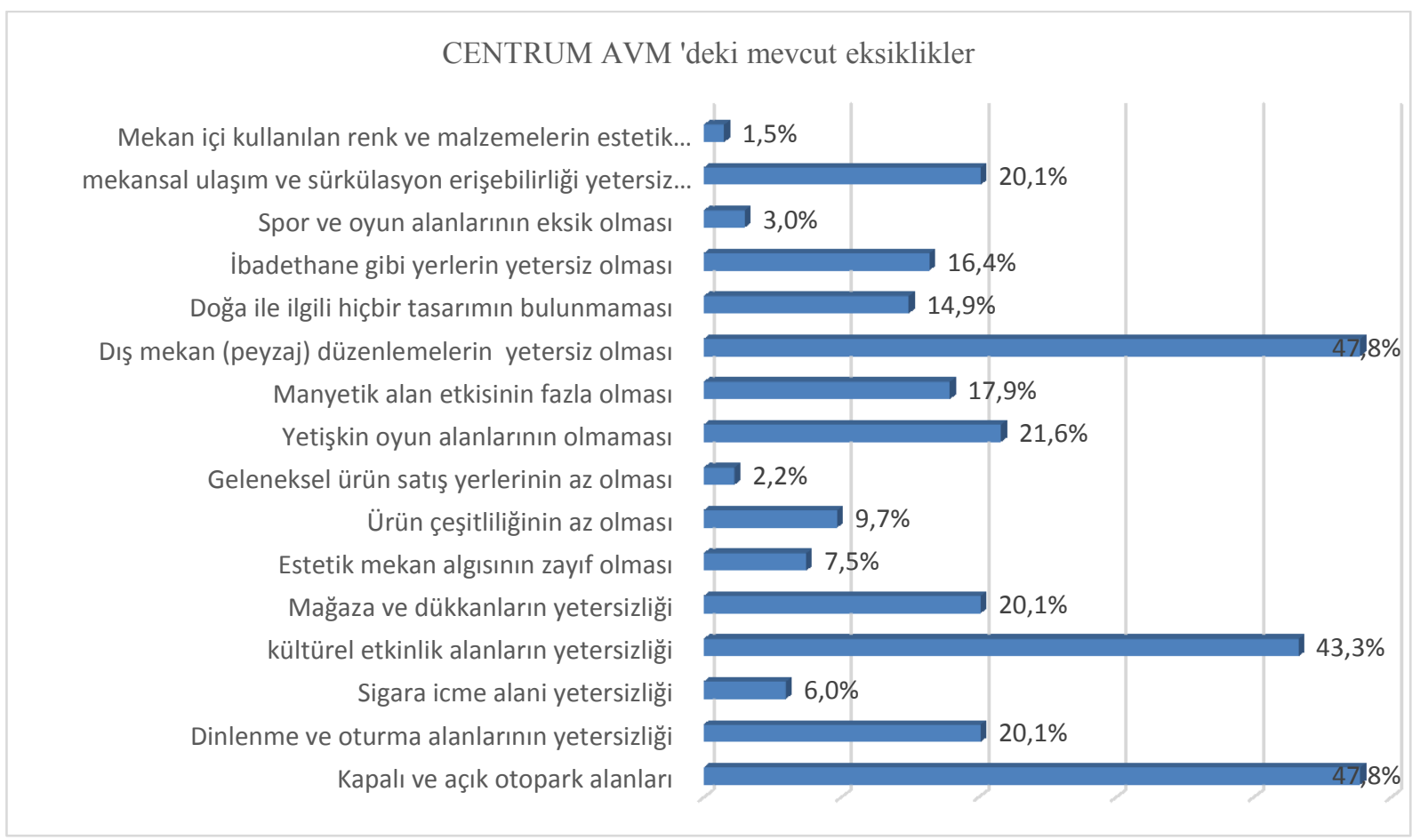

Şekil 3.11. CENTRUM Garden AVM'de mevcut eksikliklerin yüzde oranları

\subsection{Kullanıcıların Isparta AVM'ler İçin Talep ve Eğilimlerinin İrdelenmesi}

Ankete katılanların mevcut Isparta AVM'ler ile ilgili eğilim ve beklentileri açısından irdelendiğinde;

Kentsel mekân kullanımına açısından cinsiyet faktörüne göre önemli farklılıkların olduğu gözlenmektedir. Örneğin kadınların \%54'ü ve erkeklerin \%34,6'sı AVM'yi tercih ederken, erkeklerin $\% 26,9^{\prime}$ u özellikle çay bahçesi, kahvehane gibi alanları tercih ederken, kadınların ise sadece \%0,6'sı tercih etmektedir (Çizelge 3.3.1). Aslında kadınların daha fazla alış veriş yapma eğilimde olduğu öngörüsü ile kadınların öncelikli olarak AVM'leri tercih etmeleri bunu kanıtlamaktadır. Anket çalışmasında Isparta kentsel mekânların içinde en fazla Isparta AVM'lerin tercih edildiği (toplamda \%47) de görülmektedir.

Çizelge 3.3.1. Kentsel mekân tercihlerinin cinsiyete göre yüzde dağılımları

\begin{tabular}{lll}
\hline & Kadın & Erkek \\
\hline AVM & $54,9 \%$ & $34,6 \%$ \\
Kafeterya & $29,3 \%$ & $25,0 \%$ \\
Restoran & $14,0 \%$ & $10,6 \%$ \\
Kapalı spor ve oyun alanları & $1,2 \%$ & $2,9 \%$ \\
Çay bahçeleri, kahvehane, vb & $0,6 \%$ & $26,9 \%$ \\
\hline
\end{tabular}

Pearson Chi-Square, Value:48,242, df 4, 0,000

*AVM'lerin mevsimsel kullanımı açısından cinsiyet faktörüne göre önemli bir farklılık ortaya çıkmamıştır. Örneğin kadınların büyük bir çoğunluğu $(\% 42,7)$ ve erkeklerin \%44,2 si özellikle kış mevsimini ilk sırada tercih etmiştir (Çizelge 3.3.2).

*AVM'lerin özellikle soğuk ve yağışlı hava koşullarında gezilebilecek ve dinlenebilecek en önemli mekânların başında gelmektedir. Aslında AVM'lerin her yerde uygulanabilen küresel mekân dili, 
doğru aydınlatma ve iklimlendirmenin de yardımıyla (gece-gündüz, yaz-kış gibi ayrımların ortadan kaldırılması) zamandan ve mekândan bağımsız bir biçimlenme ve her mevsim kullanımı esas alan bir yaklaşımdır. Bu tür bir mekân organizasyonu, yapının kendi soyut ve mekanik zamanını yaşatmasına ve kullanıcıya da bunu dayatmasına neden olmaktadır (Birol, 2003). Bu durumda, bu mekânda alışveriş mekanik bir etkinliğe dönüşürken, alışveriş merkezinde yaratılmak istenen kent merkezi görüntüsü, yerini mekanik ve tümüyle ticarileşmiş bir mekân organizasyonu oluşturulmasına yol açmaktadır. Özer ve Önal (2016) tarafından Erzurum kentinde yapılan anket çalışmasında, mevsimsel olarak kullanıcıların \%18'i yaz mevsiminde AVM'leri tercih ederken, kışın ise \%48'e ulaştığı belirtilmektedir.

Çizelge 3.3.2. AVM'lerin mevsimsel tercihlerin cinsiyete göre yüzde dağılımları

\begin{tabular}{lll}
\hline & Kadın & Erkek \\
\hline Kış & $42,7 \%$ & $44,2 \%$ \\
Bahar & $9,8 \%$ & $13,5 \%$ \\
Yaz & $1,2 \%$ & $5,8 \%$ \\
Sonbahar & $7,3 \%$ & $5,8 \%$ \\
Hepsi & $39,0 \%$ & $30,8 \%$ \\
\hline
\end{tabular}

*AVM'lere ziyaret etme sıklığı açısından genel ortalama olarak \%44,8 i hafta sonları tercih etmektedir. Bununla birlikte cinsiyet faktörüne göre önemli farklılıklar da mevcuttur. Kadınların büyük bir çoğunluğu (\%48,8) hafta sonları AVM'ye giderken erkeklerin \%40,4'ü ayda 1 veya 2 gün ziyaret ettikleri görülmüştür (Çizelge 3.3.3).

Urban Land Institute (ULI) (2016) tarafından Avrupa ülkelerinde gerçekleştirilen ankete göre; tüketicilerin yüzde 80 'i ayda en az bir kez, yüzde 42 'si ise haftada en az bir kez bir alışveriş merkezini ziyaret etmektedir.

Çizelge 3.3.3. AVM’leri ziyaret etme sıklığının cinsiyete göre yüzde dağııımları

\begin{tabular}{lll}
\hline & Kadın & Erkek \\
\hline Hafta sonları & $48,8 \%$ & $38,5 \%$ \\
2 günde bir & $39,0 \%$ & $17,3 \%$ \\
Ayda 1-2 gün & $11,0 \%$ & $40,4 \%$ \\
3 ayda bir & $1,2 \%$ & $3,8 \%$ \\
\hline
\end{tabular}

Pearson Chi-Square, Value: 18,935, df 3, 0,000

*AVM'leri tercih etme nedenleri açısından cinsiyet faktörüne göre önemli farklılıklar mevcuttur. Kadınların büyük bir çoğunluğu \%29,9'u çeşitli marka mağazalarının bulunması, AVM'yi gezmek $(\% 25,6)$ ve alışveriş yapmak $(\% 20,7)$ gibi nedenlerle tercih ederken, erkekler ise başta yemek seçeneklerin fazla olması $(\% 26,9)$, olumsuz hava koşullarından dolayı AVM'yi gezmek $(\% 20,2)$ gibi nedenleri ile tercih etmektedir (Çizelge 3.3.4). 
Çizelge 3.3.4. AVM'lerin kullanım tercihlerinin cinsiyete göre yüzde dağılımları

\begin{tabular}{lll}
\hline & Kadın & Erkek \\
\hline Olumsuz hava koşullarından dolayı AVM'yi gezmek & $25,6 \%$ & $20,2 \%$ \\
Alışveriş amaçlı & $20,7 \%$ & $11,5 \%$ \\
Aktivite çeşitliliğin fazla olması & $9,1 \%$ & $17,3 \%$ \\
Şehir merkezine yakın olması & $4,3 \%$ & $5,8 \%$ \\
Yemek seçeneklerinin fazla olması & $10,4 \%$ & $26,9 \%$ \\
Çeşitli marka mağazalarının bir arada olması & $29,9 \%$ & $18,3 \%$
\end{tabular}

Pearson Chi-Square, Value: 21,437, df 5, 0,001

*AVM'leri ziyaret ettiklerinde kalış süresi açısından cinsiyet faktörüne göre önemli farklılıklar mevcuttur. Kadınların büyük bir çoğunluğu \%56,1'i 2-4 saat arasında vakit geçirirken erkeklerin ise $\% 57,7$ si 2 saatten az sürede vakit geçirmektedir (Çizelge 3.3.5). Bu sonuç Kadınların erkeklere göre gezmek ve alışveriş için AVM mekânlarını tercih ettiklerini ortaya koymaktadır. Özer ve Önal (2016) Erzurum kentindeki AVM'lerde kullanıcıların zaman geçirme açısından değerlendirildiğinde yaz aylarında 1-2 saat geçirenlerin oranı \%39, 2-3 saat geçirenlerin oranı \%27 iken kış aylarında 1-2 saat geçirenler $\% 36$, 2-3 saat geçirenler ise $\% 24$ ' olduğu belirlenmiştir.

Çizelge 3.3.5. AVM 'lerde kalış süresinin cinsiyete göre yüzde dağılımları

\begin{tabular}{lll}
\hline & Kadın & Erkek \\
\hline$<2$ saat & $29,3 \%$ & $57,7 \%$ \\
$2-4$ saat & $56,1 \%$ & $40,4 \%$ \\
$4<$ saat & $14,6 \%$ & $1,9 \%$ \\
\hline
\end{tabular}

Pearson Chi-Square, Value: 13250, df 2, 0,001

\begin{abstract}
*AVM'lerde öncelikli olarak tercih edilen kriterlerin başında konsept gereği çok sayıda ve markalı mağaza ve dükkanların bulunması, güvenli olması, kültür etkinlik alanların (tiyatro, sinema, sergi salonları vb.) olması, dış mekân düzenlemeleri, kapalı alanda kolaylıkla gezilebilmesi ve yiyecek ve içecek yerlerinin olması gibi kriterler gelmektedir. Erkip (2005), Ankara'daki AVM'lerle ilgili yapılan bir çalışmada, bunların güvenli alanlar olmasının çekici bir özellik kattığı sonucuna ulaşmıştır. Türkiye kentleri güvenli yerleşim alanları olmasına rağmen, alışveriş merkezlerinde bulunan özel güvenliğin pazarlamada olumlu bir etken olarak başarıyla kullanıldığını ifade etmektedir. Bununla birlikte, aynı çalışmada, AVM'lerde bulunan yeme-içme alanları ile gezinme yerlerinin buralarda toplumsal etkileşim olanağı yarattığı bu nedenle tercih etmede önemli rol üstlendiğini belirtmektedir.
\end{abstract}

Urban Land Institute (ULI) (2016) tarafından gerçekleştirilen ankete göre; katılımcıların çoğunluğu ve özellikle gençlerin, ziyaret edecekleri veya alışveriş yapacakları mekâna karar vermeleri aşamasında; yiyecek ve içecek mekânları büyük ölçüde etkili olduğunu ve özellikle geleneksel gıda zincirleri yerine etnik restoranlar ve gurme dükkanların yaygınlaştığı ifade etmektedir. Nitekim bu çalışmada ankete katılanların \% 49,3'ünü öğrenci kitlesi oluşturmaktadır. Öğrencilerin en çok tercih ettikleri mekânların başında yiyecek ve içecek yerleri oluşturmaktadır. Özer ve Önal (2016) Erzurum kentindeki kullanıcıların AVM'leri tercih etmelerinin ilk sırasında özellikle ulaşım kolaylığı, iklim koşullarının karşı korunaklı olması, güvenli olması, kalitenin olması, temiz olması, otopark hizmetinin olması gibi kriterlerden dolayı tercih etmektedir. 
*Isparta AVM'lerde eksiklik olarak görülen ve yetişkinler için oyun alanları ve zaman geçireceği alanların öngrülmesi de ilginç bir sonuçtur. AVM'lerde kadınların alışveriş için uzun süreli gezmeleri erkekler tarafından rağbet görmemekte ve vakit geçirecekleri mekânlara ihtiyaç duyulması sonucunu doğurmaktadır. Urban Land Institute (ULI) (2016), Hollanda'da Hoog Catharijne Man Cave adlı bir projede, eşleri veya arkadaşları alışveriş yaparken erkeklerin de vakit geçirmek için bir elektronik mağazasının hemen yanında vakit geçirmeleri, sohbet etmeleri ve dilerlerse bir şeyler içmeleri için Cuma-Pazar arası açık olan 'boy's night out' konseptli orijinal bir mekân oluşturulması öngörülmüştür.

*Isparta'daki mevcut AVM'lerin mekânsal ve işlevsel olarak yeterli olmadığı ifade edilmiştir. Isparta mevcut IYAS ve CENTRUM Garden AVM'lerin genelde ortak eksikliklerin olduğu görülmektedir. Bunların başında AVM mekânlarının kapalı, tekdüze ve suni bir mekân konseptine sahip olması gelmektedir. Dış mekân düzenlemesinin olmaması veya açık yeşil alanlarla kombine edilmemesi önemli bir eksiklik olarak görülmektedir. Birol (2005)'e göre incelenen alışveriş merkezlerinin çoğunun mekân organizasyonunda seçeneksiz, doğrusal, dolayısıyla tekdüze ve yönlendirici bir düzenlemenin baskın olduğu ifade etmiştir. Yaptığı analizde alışveriş merkezinde kent benzeri bir mekân organizasyonu olduğunu ancak, yapıdaki meydan ve büyük mağazalar gibi düğüm noktaları ile bu bileşenleri birbirine bağlayan doğrusal dolaşım alanları arasında yaratılan gerilim ve tek doğrultulu (seçeneksiz) mekân organizasyonu, kentteki mekânsal çeşitliliğe yer vermeyerek kullanıcı hareketini yönlendirmekte ve bu tür bir mekân düzeni, hedeflenen "daha fazla tükettirme" için uygun mekânsal koşulların oluşturulduğunu ifade etmektedir. Ceylan, (2010) ise kentsel mekân olan alışveriş merkezlerinde her şeyin kusursuz olması için gösterilen çaba, alınan güvenlik tedbirleri, iklimlendirilmiş ortam steril, yapay, kurgulanmış bir kentsel mekân ortaya çıkartmak, bu durum, bireylerin mekânla arasında gerek tarihsel gerek toplumsal bağ kurmasını engellemektedir. Özer ve Önal (2016) Erzurum kentindeki AVM kullanıcıların beklentilerinin başında, mağazaların sayısı ve çeşitliliğinin artırılması, engellilere yönelik tasarımların arttırılması, kültürel-sosyal etkinliklerin ve mekânların arttırılması, mekânsal tasarımın bitki ve yapısal donatılarla yenilenmesi, temiz olması ve güvenliğin artırılması olarak sıralandığını belirtmiştir.

*Isparta AVM'lerde alışveriş amaçlı tasarlanması kullanıcıların tatmin olma düzeylerini önemli ölçüde azaltmıştır. Bu nedenle tüketicilerin sadece alışveriş yapması ve keyif duyması yeterli olmayıp alışveriş yaparken bunu aynı zamanda başka diğer eğlencelerle tamamlaması konusunda taleplerin artığı günümüzde eğlence ve alışverişin iç içe geçtiği görülmektedir (Ceylan, 2010).

\section{Sonuç ve Öneriler}

Türkiye'de sayıları son yıllarda hızla artan alışveriş merkezleri kentsel yaşamın önemli bir parçası haline gelmişlerdir. ABD, İngiltere gibi gelişmiş ülkelerin alışveriş merkezleri ile tanışıkıkları elli yıldan uzun bir süreyi kapsıyor olsa da, Türkiye için alışveriş merkezlerinin geçmişi ancak yirmi yıllık bir sürece dayanmaktadır. Türkiye'nin ilk alışveriş merkezi olan Galleria'nın 1988'de açılmasından günümüze kadar geçen bu süreç, Türkiye'nin yalnızca metropol kentlerini değil, göreceli olarak daha küçük kentleri ve hatta yerleşim alanlarını bile etkilediği görülmektedir. Türkiye'de sayıları hızla artan alışveriş merkezleri akademik literatürde pek çok tartışmanın yapılmasını gerekli kılmaktadır (Vural Aslan, 2009).

1990 yılından itibaren Türkiye'deki tüketim odaklı bir yaşam biçimi ve tüketim çılgınlığının bir yansıması olan alışveriş merkezlerinin sayısındaki çoğalma, yakın bir gelecekte beraberinde bu merkezlerin bir kısmının tercih edilmemesi veya atıl hale gelmesi mümkün olabilecektir. İstanbul'un yirmi yıllık AVM seyrinde, başlangıcından günümüze bir değişim olduğu görülmektedir. Başlangıçta atriumlu (iç avlulu), çok katlı, iklimlendirme ve aydınlatma düzeni açısından benzerlikler sunan tipolojiler yaygınken, günümüzde sokak, meydan, çarşı gibi geleneksel kent mekânına özgü tipolojilerini merkeze alarak projelendirilen, bunu kimliğin ve pazarlamanın bir öğesi olarak kullanan ve belli temaları işleyen tipolojilere doğru bir geçiş görülmektedir. illk AVM'lerden Galleria, Capitol, Carusel benzer plan şemaları olan mekânsal örgütlenme sunarken, günümüzde kurulan AVM'lerin, müşterileri çekmek için gittikçe farklı stratejiler izledikleri görülmektedir. 
Son 20 yıl içinde AVM'lerde yapılan değerlendirmede, kapalı, kontrollü ve içe dönük bir tipoloji sunan alışveriş merkezlerinin 1993'ten sonra karma kullanımlı ofis, konut vb. işlevleri barındırarak kentsel ranttan en fazla yararlanmanın hedeflendiği görülmektedir.

Son yıllarda ise, mimari konseptin değiştirilerek, yapıların daha çekici ve erişilebilir olması için mekânsal kurgu açısından yarı açık ve açık peyzaj yapılanma biçimlerinin tercih edildiği izlenmektedir. Bununla birlikte, hedef kitleye göre bir ayrışmanın mimari yapılanmaya yansıtıldığı da gözlenmektedir. Bu türden projeleri, kentsel politika ortamı ve sermayenin yönlendirdiği bilinmektedir. Bununla birlikte, tasarım ve planlama açısından sorgulanmaları ve kamu önünde tartışılmaları, proje ve yatırım tipolojilerinin dönüşümünde etkili olabilecektir. Böylece kentsel doku ile bütünleşerek özel alanın kamusal alan içinde eritilmesi konusunda daha başarılı olunabileceği öngörülebilir.

Son olarak, AVM'lerin bir gerçeklik olarak kent mekânında yerini aldığı ve kamusal alan kullanımında değişiklik yarattığı bilinmektedir. Kentsel kamusal alanların, sahte kamusal mekânlar karşısında güçlendirilmesi, daha canlı ve yaşanabilir hale getirilmesi, bu alanların kullanım dengesi açısından önem taşımaktadır. Bu anlamda, kent içindeki mevcut alışveriş caddeleri ve çarşıların oluşturduğu anlamsal bütünlüğe aykırı biçimde eklemlenmiş AVM'lerin desteklenmesi, mevcut kamusal alanların canlılı̆̆ı açısından olumsuz etki yaratacaktır. Diğer yandan, bunların mimarlık ve şehircilik platformlarında tartışılmadan gerçekleşmesi, kentlerin uzun vadede geçireceği dönüşümlerin de tartışılmadığı anlamına gelmektedir. Gelecekte ortaya çıkabilecek yeni yaşam tarzları dolayısıyla yeni mekânsal süreçlerin etkilerinin öngörülmesi açısından bu tartışmalar önem taşımaktadır (Özaydın, 2009).

Türkiye'de AVM mekânlarının dünyadaki ve Türkiye'deki örnekleri ile birebir olması veya aynı şekilde tasarlanması, aynı zamanda kent insanını doğal ortamdan veya açık mekânlardan uzaklaştıran suni mekânlar haline gelmesi belki de gelecekte Türkiye'deki kullanıcı beklentilerine cevap vermemesine ve cazibelerinin yitirilebilmesine yol açabilecektir. Bu mekânları sürekli kullanan insanlarda ortaya çıkabilecek psikolojik ve fiziksel olumsuz etkilerin olabileceği de göz ardı edilmemelidir.

Alışveriş merkezleri artık günümüzde alışverişin ötesinde bir olgu haline gelmiştir. Teknolojinin internet üzerinden alışverişe sınırsız olanak sağlaması, insanların ekran başından ya da telefonları ile alışveriş yapmalarının kolaylaşması, AVM'lerin giderek daha çok sosyal ve eğlence gibi vakit geçirebileceği rekreasyonel açık ve kapalı mekânlar haline dönüşmesini hızlandıracaktır. Bu nedenle AVM'nin mimari konseptinin gelecekteki koşullara göre yeniden gözden geçirilmeli ve tasarlanmalıdır.

Dolayısıyla, bundan sonraki süreçlerde alışveriş merkezlerinin sosyal, ekonomik, mekânsal ve yönetimsel boyutları ile ilgili tasarımcılar, plancılar, karar vericiler ve yöneticiler toplumun beklentilerine veya kullanıcı yaşamsal kalitesine yönelik birlikte ortak hareket etmeleri gerekmektedir.

Bu bağlamda mevcut ve yapılacak AVM lerin mutlaka açık ve yeşil alan ile kombine edilmesi çok amaçlı ve her mevsim kullanılabilecek şekilde işlevselliklerinin olması öngörülmelidir. Isparta kentinde faaliyet gösteren AVM'ler için mekânsal kullanımına yönelik öneriler;

- Isparta kentindeki mevcut AVM'lerin mimari konsepti diğer AVM'lerdeki gibi tekdüze, monoton ve kapalı mekân konsept özelliğindedir. Iki AVM 'nin en önemli eksikliklerin başında peyzaj alanlarının ve otoparklarının yetersiz olmasıdır. Bu nedenle mevcut benzerleri değil kendine özgü ve temalı mimari konsepti kapsamında ve Isparta kentinin her yaş grubuna yönelik ihtiyaçların karşılanması bağlamında nitelik ve nicelik olarak geliştirilmesi hedeflenmelidir.

- Mevcut AVM'lerin çevresi ile yeniden ilişkilendirilmeli ve peyzaj mekânları yapısal ve bitkisel tasarımı ile birlikte yeniden kurgulanmalıdır. 
- Mevcut AVM'lerin kapalı AVM tipolojisi yerine kompleks AVM işlevselliğine kavuşturulması ve kentsel mekânlardan kopuk değil aksine organik bağlantısı kurulacak şekilde yeniden kurgulanmalı ve özellikle zemin katların dışarıya açılması ile AVM'ler yarattıkları yeni akslarla sokağa ve kente açılması hedeflenmelidir. Özellikle AVM'lerin konumlandığı yere göre dış mekânla (peyzaj) veya sokak kültürü ile bütünleşen AVM modeli öngörülmelidir.

- Mevcut AVM'lerde iç mekân düzenlemelerinde güvenlik ve kalite hedeflerinden kesinlikle taviz verilmemelidir.

- AVM'lerde çocuk, aile, gençler ve özellikle fiziksel dezavantajı bireylere yönelik temalar ön plana çıkarılmalıdır.

- $\quad$ AVM'lerde yoğun gözlenen ve hissedilen manyetik etkilerin azaltılması için ekolojik tedbirler araştırılmalı ve uygulamaya sokulması gerekmektedir. AVM içinde ücretsiz WiFi hizmeti verilmelidir.

- AVM mekânlarında enerji üretimi, etkin kullanımı ve verimliliği öncelikli olarak ele alınmalı ve kendi enerjisini üretecek teknolojik alternatifler oluşturulmalı ve enerji tasarruf tedbirleri uygulanmalıdır.

- AVM kullanıcılara yönelik sadece çocuk oyun alanları değil aynı zamanda yetişkinlere yönelik zaman geçirecekleri oyun ve dinlenme alanları da öngörülmeldiir.

- AVM'lerde mekânsal mimari malzeme ve objeler tematik olmall, estetik ve işlevsel olarak yeniden kurgulanmalıdır. AVM içinde yeterli düzeyde sirkülasyon ve kısa sürede erişebilirlik seçenekleri artırılmalı özellikle çok katı AVM’lerde asansör kapasitesi ve sayısı artırılmalıdır.

\section{Kaynaklar}

Backes, N. (1997). Reading the Shopping Mall City", Journal of Popular Culture, 31 (3) 1-17.

Birol, G. (2003). Evolution of Trade Centres in Relation to Changing Trade Activities, basılmamış Doktora Tezi, İzmir Yüksek Teknoloji Enstitüsü, 2003.

Birol, G. (2005). Çağdaş Alışveriş Merkezlerinde Kent Dokusunun Yeniden Yorumlanması. Gazi Üniv. Müh. Mim. Fak. Der. Cilt 20, No 4, 2005.

Ceylan, M.N. (2010). Tüketim Toplumunun Yeni Kentsel Mekânı: Alışveriş Merkezleri. T.C. Selçuk Üniversitesi Sosyal Bilimler Enstitüsü Sosyoloji Ana Bilim Dalı, Yüksek Lisans Tezi, Konya - 2010

Erkip, F. (2005). The rise of the shopping mall in Turkey: the use and appeal of a mall in Ankara, Cities, 2 (22), $89-108$

Gruen, V. (1960). Shopping Towns USA, Van Nostrand Reinhold, New York, 1960.

Gruen, V. (1973). Centers for the Urban Environment: Survival of the Cities, Van Nostrand Reinhold Company, New York.

Kowinski, W. S. (1985). The Malling Of America: An Inside Look At The Great Consumer Paradise, W. Morrow, New York.

Odabaşı, Y. (1999). Tüketim Kültürü: Yetinen Toplumun Tüketen Topluma Dönüşmesi, Sistem Yayıncılık, İstanbul.

Özaydın, G. (2009). Büyük Kentsel Projeler Olarak Alışveriş Merkezlerinin İstanbul Örneğinde Değerlendirilmesi. MiMARLIK 347, Mayıs-Haziran,2009. http://www.mimarlikdergisi.com/index.cfm?sayfa=mimarlik\&Dergi Sayi=361\&RecID=2074.

Özer, S. ve Önal, E. (2016). Alşveriş merkezlerinin mevsimlere göre rekreasyonel tercih nedenlerinin belirlenmesi; Erzurum Kenti Örneği. International Winter Cities Symposium. Proceedings.10-12 February 2016. Erzurum. P.684-698. ISBN No: 978-975-442-811-7. 
Tokatlı, N. ve Boyacı, Y. (1999). The Changing Morphology of Commercial Activity in Istanbul, Cities, 3 (16),181193.

Urban Land Institute (ULI), (2016). Kaynak //http://www.gazete2023.com/ekonomi/avm-mi-cadde-magazaciligi -mi-h53616.html Gazete2023 (Erişim Tarihi: 15.Eylül 2016).

Vural Aslan, T. (2003). Değişen Üretim-Tüketim Iliş̧kileri ve Alışveriş Merkezleri: Eleştirel bir Bakış, Arredamento Mimarlık, 6, 82-87

Vural Aslan, T. (2009). Türkiye'deki Alışveriş Merkezleri İncelemelerine Eleştirel Bir Bakış: Yorumlar, Eleştiriler, Tartışmalar. Uludağ Üniversitesi Mühendislik-Mimarlık Fakültesi Dergisi, Cilt 14, Sayı 1, 2009.

Yazıcıoğlu, Y. ve Erdoğan, S. (2004). SPSS Uygulamalı Bilimsel Araştırma Yöntemleri, Detay Yayıncılık, Ankara

White, R. and Sutton, A. (2001). Social Planning for Mall Redevelopment: an Australian Case Study, Local Environment, Cilt 6, No 1, 65-80, 2001.

Zukin, S. (1998). Urban Lifestyles: Diversity and Standardisation in Spaces of Consumption, Urban Studies, Cilt:35, Sayı:5-6, ss.825-839. 